\title{
Impact of different factors on biogas production in poultry dropping based biogas plants of Bangladesh
}

\author{
Mohammad Shariful Islam ${ }^{1}$, Asif Islam ${ }^{2}$, Dipendra Shah ${ }^{3,}$, Enamul Basher ${ }^{1}$ \\ ${ }^{1}$ Electrical \& Electronic Engineering, Bangladesh University of Engineering \& Technology (BUET), Dhaka, Bangladesh \\ ${ }^{2}$ Planning \& Development Division, Power Grid Company of Bangladesh (PGCB) Ltd., Dhaka, Bangladesh \\ ${ }^{3}$ NIS Department, Huawei Technologies Co. Ltd., Kathmandu, Nepal
}

\section{Email address:}

sabuz03@gmail.com (M. S. Islam), asif038@gmail.com (A. Islam),dipendrashah@gmail.com (D. Shah), enamul_basher@eee.buet.ac.bd (E. Basher)

\section{To cite this article:}

Mohammad Shariful Islam, Asif Islam, Dipendra Shah, Enamul Basher. Impact of Different Factors on Biogas Production in Poultry Dropping Based Biogas Plants of Bangladesh. Journal of Energy and Natural Resources. Vol. 2, No. 4, 2013, pp. 25-32.

doi: 10.11648/j.jenr.20130204.11

\begin{abstract}
Bangladesh, with poultry farms number of 215000 and poultry population of 200 million, has a potential of 1.33TWhr electricity per year. Despite of this huge potential, only few number of biogas plants have been deployed till date. Besides, most of these plants are unable to produce the expected amount of biogas as most of the digesters of these plants are made locally and they don't have any scheme for monitoring and controlling temperature, $\mathrm{pH}$, bacterial population in digester, mixture of different substrate, hydraulic retention time, total solid (TS), periodic agitation, periodic loading and unloading of substrate etc. But, there is few bigger size plants which contain imported digesters equipped with monitoring and controlling schemes, hence they produce bigger amount of biogas. In this study, an analysis has been done focusing the impacts of above mentioned factors on biogas production by comparing biogas production between locally made digesters and imported digesters. The result reveals that up to $75 \%$ more biogas is generated in imported digesters than the locally made digesters.
\end{abstract}

Keywords: Digester, Anaerobic Digestion, Psychrophilic, Mesophilic, Thermophilic, Hydraulic Retention Time

\section{Introduction}

In Bangladesh only $3 \%$ of the people enjoy the facility of natural gas coming to their homes through pipe lines. The lucky few mostly live in the cities. Most of the Bangladesh's rural people depend on biomass, crop residues, plant debris, animal dung and wood for fuel creating deforestation, flood, soil erosion etc. Women and children, on whom the burden of collecting fuel falls, suffer the most. They are the worst victims [1] of indoor air pollution such as smokes in the kitchens. Biogas technology is one of the best means [2] to provide natural gas to the largest number of rural people. It can provide them with pollution free, efficient energy for cooking and at the same time protect them from diseases by giving them a cleaner environment. Biogas technology can be used to implement a sustainable waste management program suitable for rural areas, as wastes of all sorts are transformed into biogas or slurry. Besides, biogas can be used to produce electricity for poultry farm itself to reduce farming cost as well as household use. According to the Bangladesh Bureau of Statistics (BBS) the number of poultry farms [3, 4] in Bangladesh was 49825 in 2007-08. Out of which 33225 were broiler farms, 10099 were layer, 227 were hatchery, 5524 were duck and 750 were duck farms. The annual growth rates of those farms were $28 \%$, $18 \%, 20 \%, 22 \%$ and $9 \%$ respectively. According to International Finance Corporation (IFC), the number of poultry farms in Bangladesh is 215000 . From the poultry droppings and litter, biogas can be produced [5]. This biogas can be used for daily cooking, lighting or electricity generation. Different poultry birds give different amount of droppings. Hence different amount of biogas is produced from different type of birds [6]. Breeder birds give approximately $245 \mathrm{gm}$ of droppings, whereas other birds give around $100 \mathrm{gm}$ of droppings per day. Almost thirty thousand tons of droppings are projected to be generated. If all these droppings can be used for generation of biogas then a great amount of energy [7-10] could be produced. The usual solid contents of the droppings are about $20 \%$. Biogas produced from per $\mathrm{kg}$ of solid content is about $0.4 \mathrm{~m}^{2}$. $1 \mathrm{kWhr}$ of electricity can be produced from 22.4 CFT of biogas according to BCSIR. About 82 million CFT of biogas 
can be produced per day which is equivalent to 30 billion CFT of biogas per year. These amounts of biogas can produce $3.65 \mathrm{GWhr}$ of electricity per day which is equivalent to $1.33 \mathrm{TWhr}$ per year [9]. For 14 hours of operation this biogas can run a $260 \mathrm{MW}$ generation unit. Biogas plant can supply required electricity to the poultry farm itself and to the neighboring localities where national grid power is not available. This will also reduce $\mathrm{CO}_{2}$ emission, alleviate environmental pollution, bad odor produced in poultry farms, create job scopes for people of the adjacent area, mitigate the stress on the national grid and can generate revenue selling organic fertilizer. Besides, efficient management of produced biogas, electricity and heat wastage will provide the maximum benefit out of the available resources. Despite all these prospects only a limited number of biogas plants are deployed in the poultry farms of Bangladesh. Besides, plants already deployed are not managed properly [11] which reduces the production of biogas hence the efficiency. There are different factors which influence the production of biogas e.g.-temperature, $\mathrm{pH}$, bacterial population in digester, mixture of different substrate, hydraulic retention time, total solid (TS), periodic agitation, periodic loading and unloading of substrate etc. This study is aimed at to reveal the influence of these factors on biogas production in biogas plants deployed in poultry farms.

\section{Methodology}

For technical and economical success insuring stability process and maintaining required quality and quantity of gas is a prerequisite [12]. To maintain these prerequisite following conditions must always be fulfilled:

- Anaerobic condition in the digester must be maintained.

- Temperature must me controlled to the permissible values.

- Availability of nutrients for bacteria;

- Substantial amount of nutrients bacteria must always be present in the digester.

- Substrate must be loaded and unloaded periodically.

- $\mathrm{C} / \mathrm{N}$ ration must always be observed and work accordingly.

- Correctly chosen proportion of solids content and proper agitation;

- Absence of inhibitors of the digestion process

\subsection{Temperature}

Temperature has the most pronounced impacts on anaerobic digestion. It has three main temperature ranges: from $10-25^{\circ} \mathrm{C}$ (psychrophilic conditions), from $30-37^{\circ} \mathrm{C}$ (mesophilic conditions) and from $48-55^{\circ} \mathrm{C}$ (thermophilic conditions) [13]. Psychrophilic digestion process is very slow hence only mesophilic and thermophilic digestion processes are used in practice. At very low or high temperature the activities of bacteria population is almost stopped consequently the digestion process is becomes very long. Hence the production of biogas is reduced. The methane content becomes very low. As a result the produced biogas cannot be used as fuel for electricity generation and cooking [12-15].

\section{2. pH Value}

The $\mathrm{pH}$ of the digester is a function of the concentration of volatile fatty acids produced, bicarbonate alkalinity of the system, and the amount of carbon dioxide produced. The optimum range of $\mathrm{pH}$ for biogas production is between 7.0 and 7.2 [16]. But the substantial biogas can be produced for the $\mathrm{pH}$ range of 6.6 to 7.6. Biogas production reduces many fold for the $\mathrm{pH}$ value of less than 5 as the bacteria population decrease significantly under the circumstances.

\subsection{Bacterial Population in Digester}

Digester must always contain a certain amount of bacteria for acceptable amount of biogas production. Any dip in bacteria population impedes the production of biogas. Addition of enzymes enhances the bacteria population which in turns increases biogas production [13].

\subsection{Mixture of Different Substrates}

As different substrate produce different amount of biogas, the mixture of them increases the biogas production and methane content [10].

\subsection{Hydraulic Retention Time (HRT)}

The Hydraulic retention time (HRT) is also known as hydraulic residence is the time required for complete digestion of the substrates in Digester. Hydraulic retention time is the volume of the digester divided by the influent flow rate.

HRT = Volume of Digester / Influent Flow Rate where using SI UnitsVolume is in $\left[\mathrm{m}^{3}\right]$ and Influent flow rate is in $\left[\mathrm{m}^{3} / \mathrm{h}\right]$. HRT is usually expressed in hours (or sometimes days).

\subsection{Total Solid (TS)}

Total solid contained in a certain amount of materials is usually used as the material unit to indicate the biogasproducing rate of the materials. Most favorable TS value desired is $8 \%$.

\subsection{Daily Substrate Input}

The daily substrate input depends on the HRT of the digestion process. The HRT can be 10 days to 80 days. If digester HRT is 10 days, than daily substrate load will be $1 / 10$ from the overall volume of substrate in digester. For biogas plants working in thermophilic range, daily substrate load can constitute up to $1 / 5$ of overall substrate volume in digester.

\subsection{Substrate Digestion Time}


Choice of substrate digestion time depends also from the type of substrate used. Cattle substrate takes 10-15 days, pig manure 9-12 days, poultry manure 10-15 days and 40-80 days manure mixed with vegetation waste for complete digestion [14].

\subsection{C/N Ratio}

For optimal $\mathrm{C} / \mathrm{N}$ ratio different substrates are mixed for which maximizes the production of biogas.

\subsection{Regular Agitation}

For maximizing the production of biogas regular agitation of substrate in digester is required. The regular agitation frees the produced biogas entrapped in the substrate, mixes the fresh substrate with bacteria population, prevents scum and sediment, prevents temperature gradient inside the digester, provides the homogeneous mixture of bacteria population and prevents the formulation of voids.

\section{Study Area}

In Bangladesh two types of digesters are used for biogas production in poultry farms [9]. The large portions of these digesters are locally produced and are used for smaller size of biogas plants. But in larger size of plants the digesters are imported from abroad.

Locally produced digesters are made of concrete and are of low costs. But no control system is available for these digesters. Hence they produce less biogas. On the other hand, imported digesters are made of steel, bigger in size and cost higher. But as they have control system for controlling above factors they generate larger amount of biogas.

There are numerous biogas deployed in different parts of Bangladesh. Paragon Poultry Limited (PPL), one of the biggest poultry farms in Bangladesh, has deployed biogas plants at Gazipur, Mymensigh, Rangpur and Sylhet. One plant is ready to operate at Panchagarh also. We have surveyed biogas plants in Gaziupur, Mymensingh and Rangpur, and also collected information about Sylhet and Panchagarh plants. Felix Energy Service (FES), a Danish company for setting biogas power plant, in collaboration with Computerized Service Centre (CSC) of Narayanganj has set up more than 20 biogas plants in poultry farms of different parts of Bangladesh. A few of them has been surveyed and also information has been collected for remainder of them. Local companies and FES have set up the biogas plants; FES and CSC have provided all the equipments. There is another biogas plant set up by individuals in Rangunia, Chittagong for household electricity generation. The plants generate $6.4 \mathrm{~m}^{3}$ to $4000 \mathrm{~m}^{3}$ of biogas. Out of 18 (Figure 1) plants first 16 are using digesters with local materials and last two are using imported digesters. One plant is using local equipments which includes generator. 13 are using local equipments and assembled generators. 4 of them are using imported machineries. Three of them are using 2 generator units. Rests 15 are using 1 generator unit. Table 1 shows the detail of these plants.

Only 3 plants are using mixing tanks, all of them are of PPL. Most of them are using 1 digester, but Rangpur is using 4 digesters and Gaziupur using 2 digesters. Only three are using separate holding tanks and only two of them are using how water tank for temperature control.

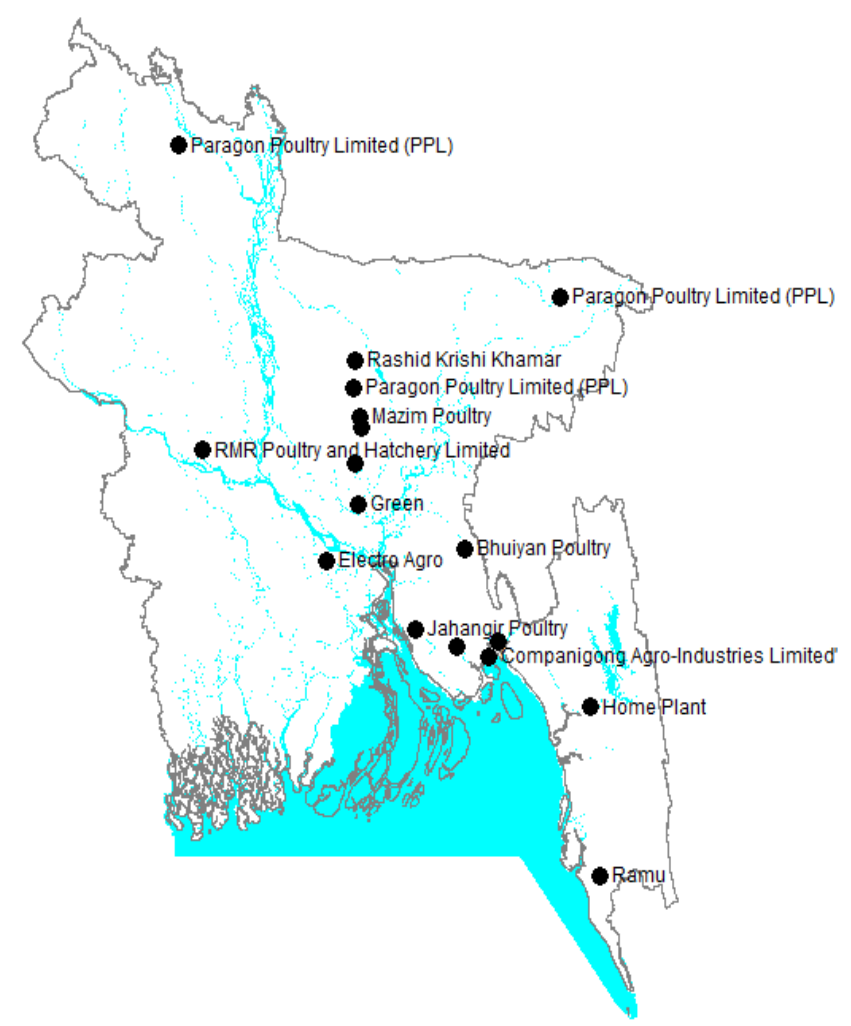

Figure 1. Locations of different biogas plants in different parts of Bangladesh which are studied

\section{Results and Analysis}

Digesters can be locally built or can be imported. For both the cases the cost for per cubic meter of biogas generation is almost equal. The plant of 1200 cubic meter capacity has a bigger cost because they have designed a bigger size digester for future expansion. For locally converted generators the overall costs remain constant and much smaller than the plants with imported equipments. The generation cost per kWhr of electricity is given by the Figure 2.

The digester cost remains fairly constant for all scale of generation. Generator cost for locally converted biogas generators remain small, but for imported generator the cost is fairly high. Other costs remain fairly constant all over.

The value of $\mathrm{pH}$ between 6.8 and 7.2 gives the best production of biogas. Anything outside of this range reduces biogas production. Hence it is very important to maintain the $\mathrm{pH}$. Usually $\mathrm{pH}$ of a digester is self-regulating, hence any aberration of it tend to be converged to the reference value 
on its own. But there could be cases where $\mathrm{pH}$ needed to be controlled if too much deviation is observed. Usually lime water is introduced to the digester to maintain $\mathrm{pH}$.

For locally made digesters there are no arrangements for periodic measurement of $\mathrm{pH}$ which could reduce the biogas production but for the cases of imported digesters there are arrangements for periodic $\mathrm{pH}$ measurement, but there are no automatic $\mathrm{pH}$ control arrangements, hence the onus is fully on the operator to maintain the $\mathrm{pH}$. For this research, biogas plants of Gazipur and Mymensingh have been visited which use imported digesters. The $\mathrm{pH}$ is measured and maintained regularly. Note that not every day's pH is tabulated. Only November and December's $\mathrm{pH}$ are found and it seen that the $\mathrm{pH}$ always remains 7 over the mentioned time (Figure 3 ).

Temperature of digester is the most important parameter for optimal biogas production. The average temperature over the year varies between $17^{\circ} \mathrm{C}$ to $30^{\circ} \mathrm{C}$. The maximum and minimum temperature can vary over a larger range. But the temperature should remain as close to 38 as possible for maximum production of biogas (Figure 4).

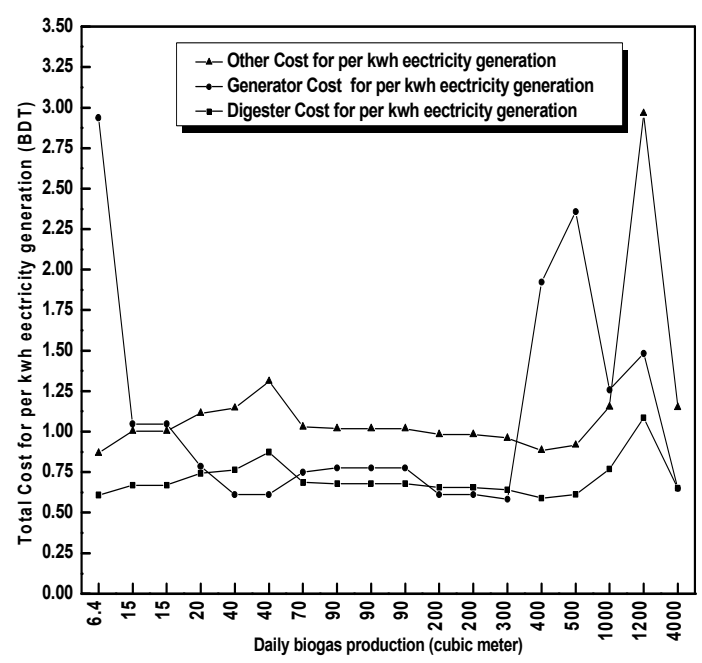

Figure 2. Total Cost for per $\mathrm{kWh}$ relectricity generation

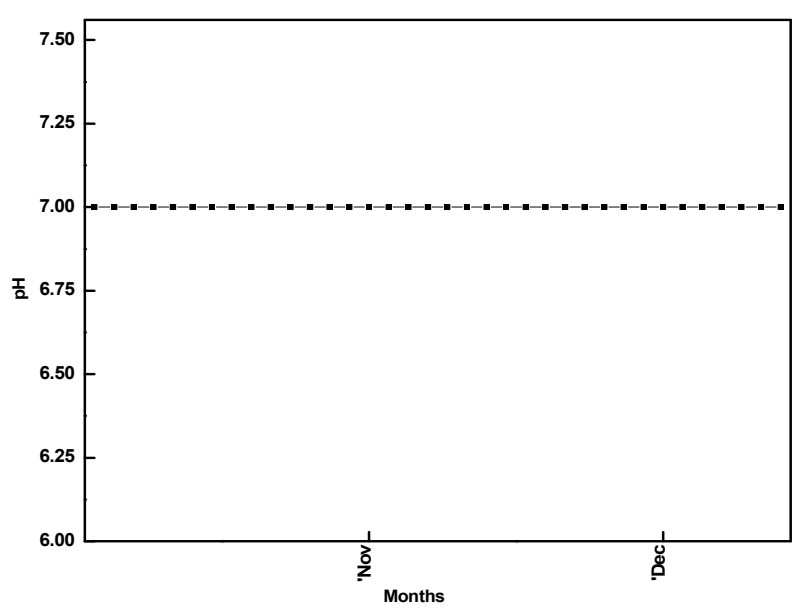

Figure 3. $p H$ of an imported digester over the different months

So if temperature is not controlled the production of biogas will vary with the variation of temperature. The variation of temperature will reduce biogas yield and methane content of the gas. Hence the air and $\mathrm{H}_{2} \mathrm{~S}$ removal unit need to work more time than usual. The running time of generator will be reduced, in turn it will reduce electricity yield. So for rated load it will increase current and reduce voltage, rotational speed and frequency. The energy of cooling water and exhaust gas can be used to control the temperature of the digester. The cooling water of the generator can be directly used to control the temperature of the digester. But this water along is not enough for the digester in an extremely cool weather. Hence the energy of the exhaust gas is used with a heat exchanger for producing more hot water. The cooler the weather the more temperature difference between the input and output of the heat exchanger will be observed. As the imported digesters have the arrangements for temperature control the subsequent figure shows the mentioned parameters for them over the year.

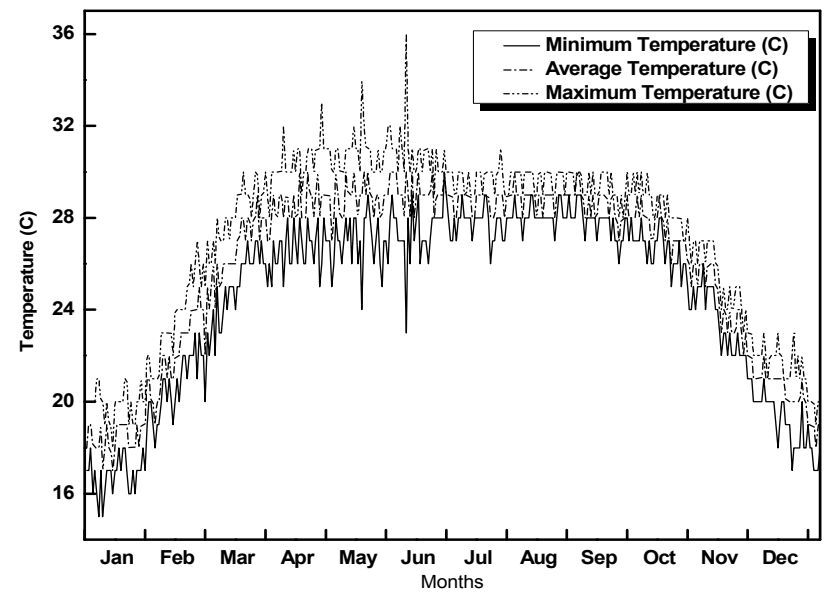

Figure 4. Average, maximum and minimum temperature throughout the year

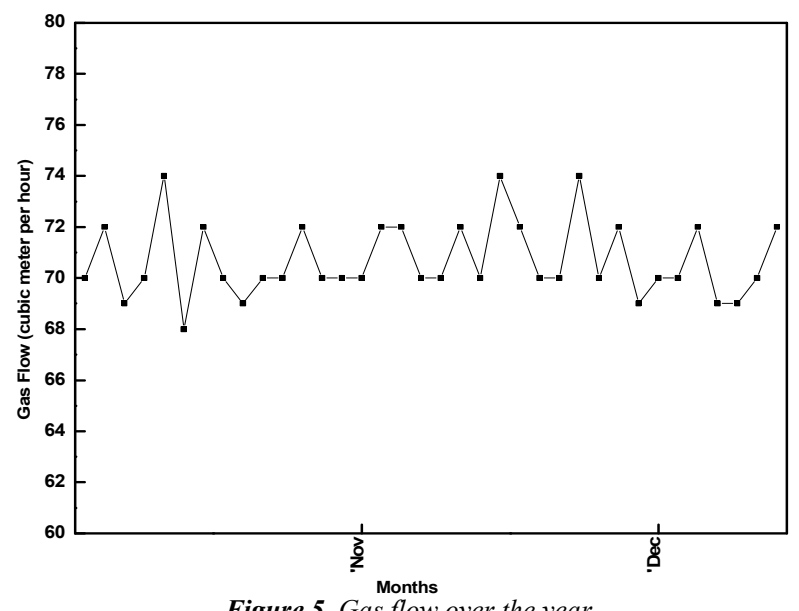

Figure 5. Gas flow over the year

Figure 5 shows that despite the temperature variations, as the temperature is controlled the biogas flow remains almost constant. The voltage remains constant at $400 \mathrm{~V}$ over the year, but current varies with variation of the load as per Figure 6 . 
The frequency remains constant $50 \mathrm{~Hz}$ over the year and rotational speed remain within $1 \%$ of the rated value over the year as shown in the Figure 7.
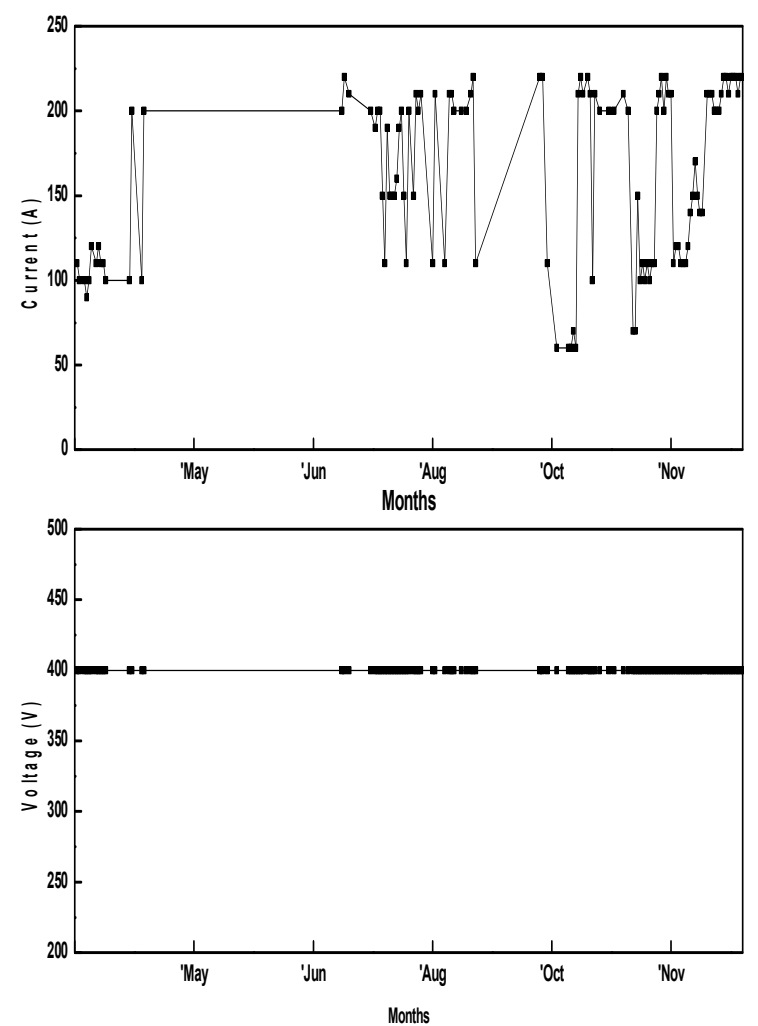

Figure 6. Voltage and current of the biogas plant with imported digester
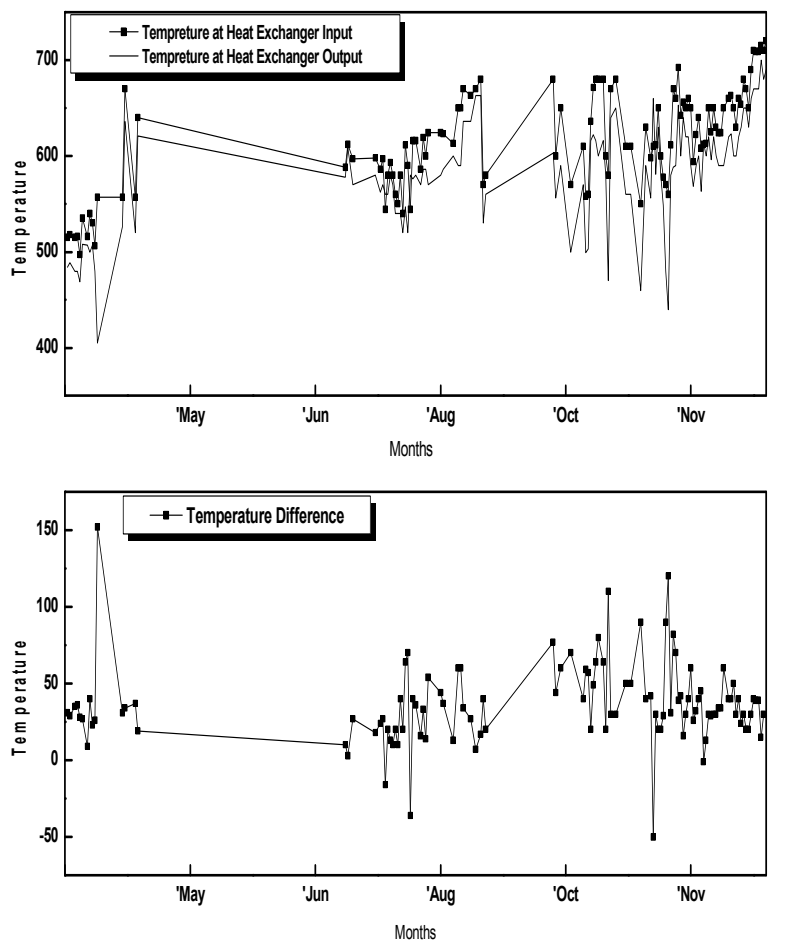

Figure 8. Temperature of exhaust at heat exchanger input and output and temperature difference
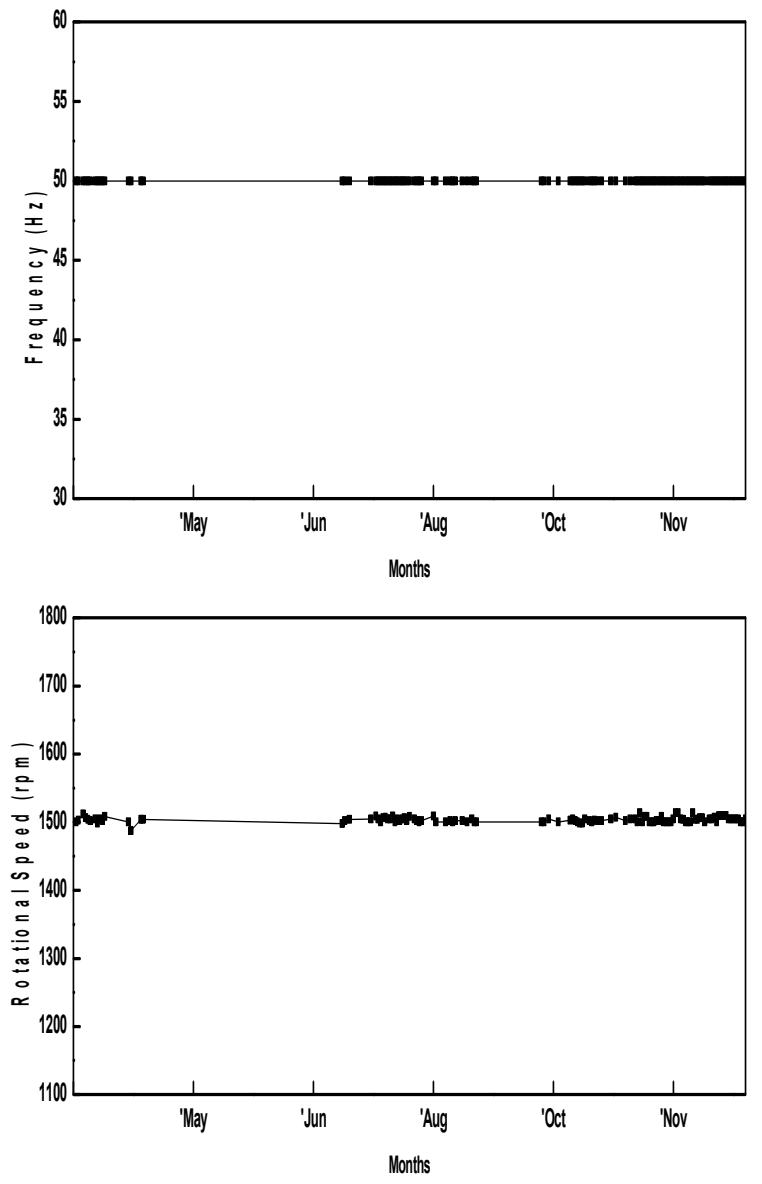

Figure 7. Frequency and rotational speed over the year for imported digester

It shows (Figure 8) that during the cooler part of the year more heat required for maintain the temperature of digester hence the temperature difference is higher, but during the hotter part of the year the temperature difference is lesser as less heat is required for maintaining the temperature of the digester.

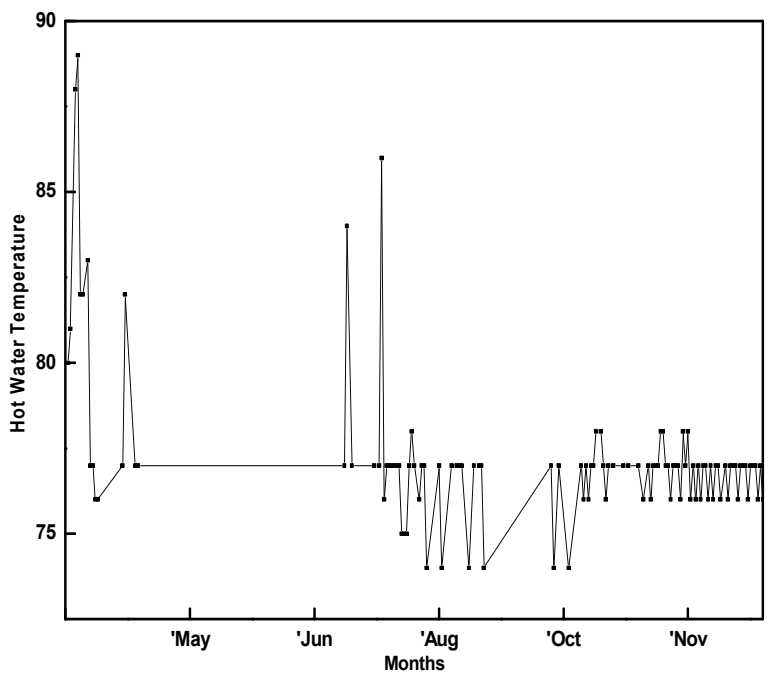

Figure 9. Hot water temperature over the year 


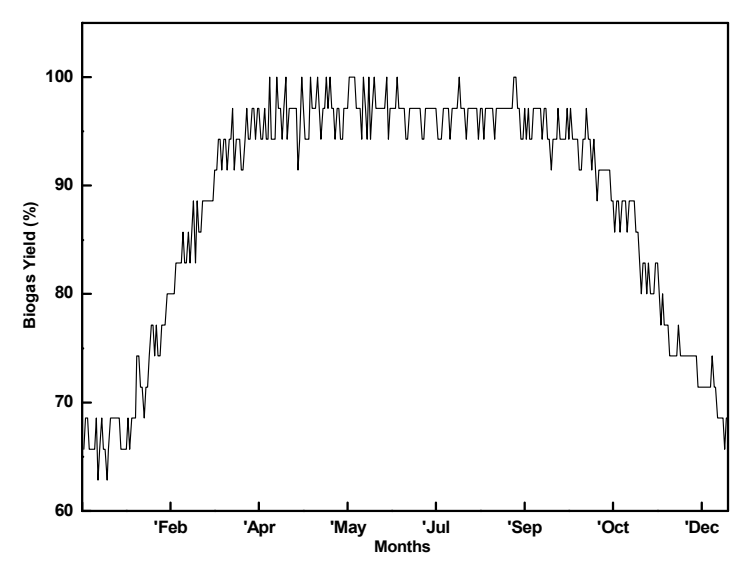

Figure 10. Biogas yield for local digesters

The hot water tank temperature (Figure 9) is maintained around 77 over the year. There cases of overshoot as well undershoot. Now for locally built digesters the temperature and $\mathrm{pH}$ are not controlled. Hence less biogas is generated. The biogas yield and methane content vary over the year, consequently electricity generation also varies. Neither biogas yield or methane content nor electricity generation is monitored for local digesters. But methane content of biogas is monitored for Rangpur Poultry Farm at Rangpur, but not tabulated. The methane content during the hotter part of the year varies among $60 \%$ to $70 \%$. But during the cooler part it can fall as low as $40 \%$. The variation of methane content as the percentage of maximum methane content can be shown by the Figure 10 .

The calculation shows that the overall biogas generation reduced by $12 \%$. For extreme cold year the generation can be reduced by up to $20 \%$.As the biogas yield decreases by $12 \%$ to $20 \%$ the generation cost increases. We shall use $12 \%$ reduction of biogas yield to calculate the generation cost of per kWhr electricity. Figure 11 below shows the normalized cost for per unit electricity generation.

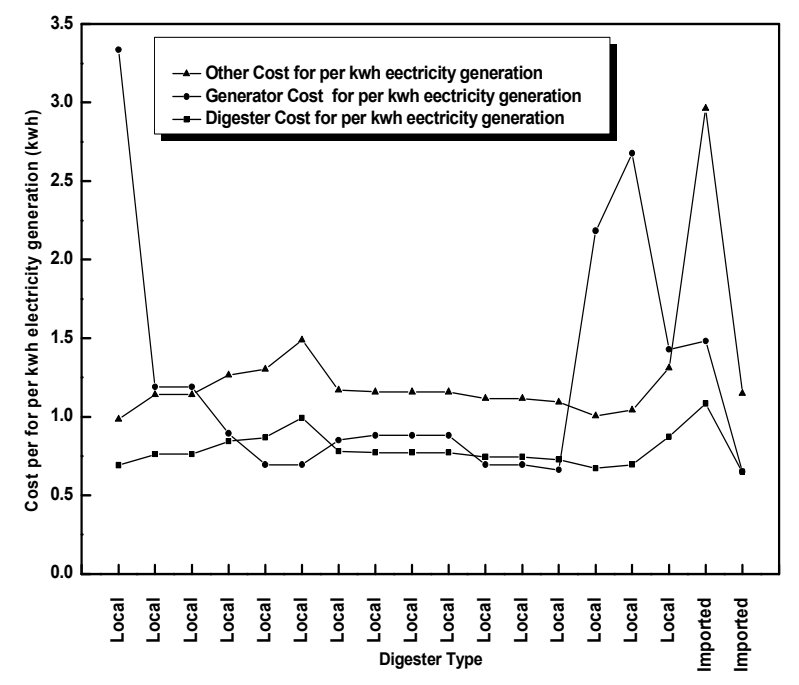

Figure 11. Cost for per $\mathrm{kWhr}$ electricity generation taking the $\mathrm{pH}$ and temperature into account
The advantage of local digester is no longer valid as the generation cost increased for per $\mathrm{kWhr}$ electricity generation.

Periodic loading and unloading and unloading are very important for maximizing the biogas production. The periodic agitation of digester and mixing tank increases biogas production. Motors and pumps are used for imported digester for loading and unloading of manure. For agitation, pumps and motors are used. At PPL manure is loaded everyday at $8 \mathrm{am}$. Before loading, unloading is also done. Everyday 20 ton manure is pumped into the mixer, after mixing for 30 minutes the manure is pumped into digester for 2 hours (Figure 12 and Figure 13).

Taking all the factors described above into account we are in the position calculate the production of biogas from two different cases. The cases are:

1) Case 1: Imported digester with all types of controlling schemes

2) Case 2: Local digester with no controlling schemes.

Table 2 shows the comparison of biogas yield between mentioned two cases. It clearly appears that the digesters with controlling schemes yields $75 \%$ more biogas. More benefits means,

1) The plants which run for 14 hours can run for 24 hours now.

2) More biogas means less generation cost for per kwh.

3) Uninterrupted power supply for 24 hours which cannot be provided by even the national grid.

4) More power from biogas means less from diesel or other sources which reduces green house gas emission.
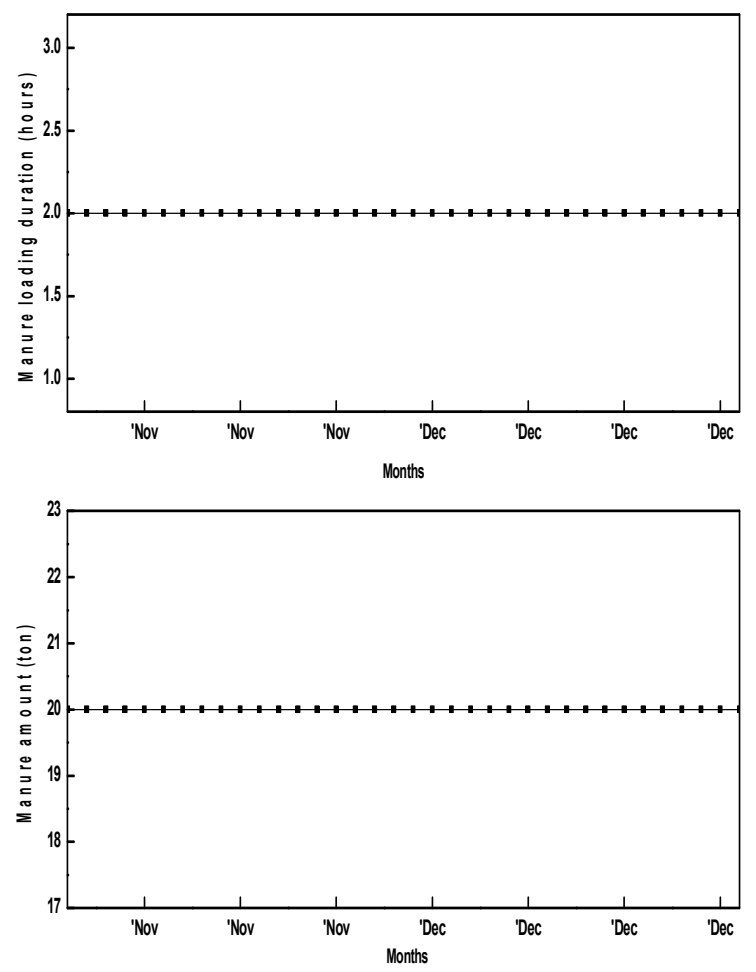

Figure 12. Manure loading duration and manure amount 

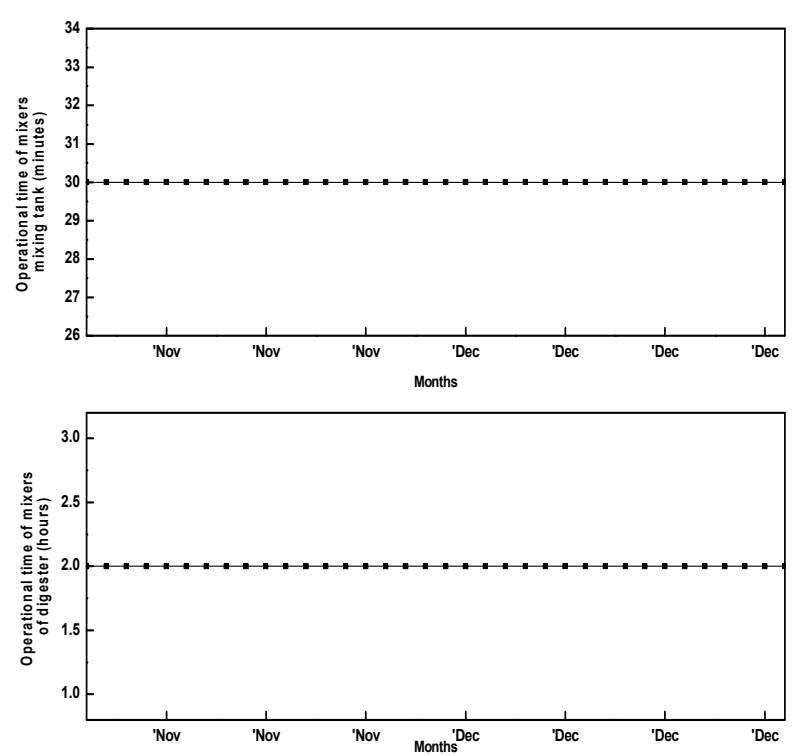

Figure 13. Operational time of mixers mixing tank (minutes) and Operational time of mixers of digester (hours)

But for generating more gas we need to deploy the controlling schemes which will,

1) Incur more cost for equipments and control module.

2) Will reduce operational cost as less operator will be required

3) Will reduce the size of the digesters as digestion with temperature control reduces the Hydraulic Retention Time (HRT) from 40 days to 20 days.

The cost of per kWhr electricity generation will be reduced for additional gas generation. Taking additional gas generation and additional investment required into account the figure (Figure 14) below shows the comparison between two cases mentioned above.

So if additional control systems are deployed in locally made digesters then $38 \%$ money is saved. The digester with less $20 \mathrm{~m}^{3}$ sizes doesn't have any advantage of using control system as most of the energy is lost in the control system.

\section{Conclusion}

This research work represents the impact of different factors on production of biogas in different biogas plants of Bangladesh. The operation of different size of biogas plants throughout the country starting from $6.4 \mathrm{~m}^{3}$ to $4000 \mathrm{~m}^{3}$ have been analyzed in this paper. The impacts of temperature, $\mathrm{pH}$, agitation periodic loading and unloading [17] on biogas yield are analyzed based on the collected data from survey, internet and other sources.

It has been found that most of the biogas plants don't have the schemes for controlling the temperature, $\mathrm{pH}$, agitation, loading and unloading apart from few of the biogas plants which are imported. These imported biogas plants are well equipped to control temperature, $\mathrm{pH}$, agitation, loading and unloading etc. Hence they produce up to $75 \%$ more biogas than the locally produced biogas plant. But for locally produced biogas plants additional controlling schemes can be provided making an additional investment. Although providing controlling schemes incurs additional costs but the increment in gas production suppresses the costs and the capital cost for per unit of electricity generation decreases by up to $38 \%$.

Table 1. Detail of biogas plants studied

\begin{tabular}{|c|c|c|c|c|c|c|c|c|c|}
\hline $\mathrm{S} / \mathbf{N}$ & $\begin{array}{c}\text { Daily Gas } \\
\text { Productio } \\
\text { n }\left(m^{3}\right) \\
\end{array}$ & $\begin{array}{l}\text { Total } \\
\text { Size } \\
(\mathbf{k W})\end{array}$ & Name & $\begin{array}{l}\text { Digester } \\
\text { Type }\end{array}$ & Address & $\begin{array}{c}\text { Mixing } \\
\text { Tank }\end{array}$ & Digesters & $\begin{array}{l}\text { Holding } \\
\text { Tanks }\end{array}$ & $\begin{array}{c}\text { Hot } \\
\text { Water } \\
\text { Tanks } \\
\end{array}$ \\
\hline 1 & 6.4 & 2.4 & Home Plant & Local & Rangunia, Chittagong & 0 & 1 & 0 & 0 \\
\hline 2 & 15 & 2 & Jahangir Poultry & Local & Laxmipur & 0 & 1 & 0 & 0 \\
\hline 3 & 15 & 2 & Green & Local & Solamasi, Keraniganj & 0 & 1 & 0 & 0 \\
\hline 4 & 20 & 2.5 & Mohammadia Poultry & Local & Chowpally, Laxmipur & 0 & 1 & 0 & 0 \\
\hline 5 & 40 & 5 & Ramu & Local & Cox's Bazar & 0 & 1 & 0 & 0 \\
\hline 6 & 40 & 6 & Vision Poultry & Local & Sonagazi, Feni & 0 & 1 & 0 & 0 \\
\hline 7 & 70 & 8 & $\begin{array}{l}\text { Companigong } \\
\text { Agro-Industries Ltd. }\end{array}$ & Local & Companiganj, Comilla & 0 & 1 & 0 & 0 \\
\hline 8 & 90 & 10 & Bhuiyan Poultry & Local & Comilla & 0 & 1 & 0 & 0 \\
\hline 9 & 90 & 10 & $\begin{array}{l}\text { RMR Poultry and } \\
\text { Hatchery Limited }\end{array}$ & Local & Laxminathpur, Rajapur, Pabna & 0 & 1 & 0 & 0 \\
\hline 10 & 90 & 10 & Nazim Poultry & Local & Mauna, Gazipur & 0 & 1 & 0 & 0 \\
\hline 11 & 200 & 24 & Electro Agro & Local & Gojaria, Shibchar, Madaripur & 0 & 1 & 0 & 0 \\
\hline 12 & 200 & 24 & Fortuna & Local & Targas, Gazipur & 0 & 1 & 0 & 0 \\
\hline 13 & 300 & 34 & Vulua Royal Chicks & Local & Sonapur, Noakhali & 0 & 1 & 0 & 0 \\
\hline 14 & 400 & 50 & Rashid Krishi Khamar & Local & Trishal, Mymensingh & 0 & 1 & 0 & 0 \\
\hline 15 & 500 & 60 & $\begin{array}{l}\text { Paragon Poultry Ltd. } \\
\text { (PPL) }\end{array}$ & Local & Sylhet & 0 & 1 & 0 & 0 \\
\hline 16 & 1000 & 100 & $\begin{array}{l}\text { Paragon Poultry Ltd. } \\
\text { (PPL) }\end{array}$ & Local & $\begin{array}{l}\text { Chandaner Hat, Gangachara, } \\
\text { Rangpur }\end{array}$ & 1 & 4 & 1 & 0 \\
\hline 17 & 1200 & 122 & $\begin{array}{l}\text { Paragon Poultry Ltd. } \\
\text { (PPL) }\end{array}$ & Imported & $\begin{array}{l}\text { Chamiadi, Valuka, } \\
\text { Mymensingh }\end{array}$ & 2 & 1 & 1 & 1 \\
\hline 18 & 4000 & 264 & $\begin{array}{l}\text { Paragon Poultry Ltd. } \\
\text { (PPL) }\end{array}$ & Imported & $\begin{array}{l}\text { Baniarchala, Bhavanipur, } \\
\text { Gazipur }\end{array}$ & 1 & 2 & 1 & 1 \\
\hline
\end{tabular}


Table 2. Amount of biogas yield from local and imported digesters

\begin{tabular}{ccccccc}
\hline $\begin{array}{c}\text { Case } \\
\text { No. }\end{array}$ & $\begin{array}{c}\text { Manure Amount } \\
(\mathbf{t} / \mathbf{d a y})\end{array}$ & $\begin{array}{c}\text { Total Solid } \\
\mathbf{( \% )}\end{array}$ & $\begin{array}{c}\text { Total } \\
\text { Solid }\end{array}$ & $\begin{array}{c}\text { Electricity Yield } \\
(\mathbf{k W h r / d a y})\end{array}$ & $\begin{array}{c}\text { Equivalent biogas } \\
\left(\mathbf{m}^{\mathbf{3}} / \mathbf{d a y}\right)\end{array}$ & $\begin{array}{c}\text { Biogas yield } \\
\left(\mathbf{m}^{\mathbf{3}} / \mathbf{k g}\right)\end{array}$ \\
\hline 1 & 20 & 0.3 & 6000 & 6300 & 4018 & 0.7 \\
2 & 0.08 & 0.2 & 16 & 10 & 6 \\
\hline
\end{tabular}

\section{Acknowledgements}

The authors would like to acknowledge the contribution of Paragon Poultry Limited (PPL), Felix Energy Services, and Computerized Service Centre for their data of biogas plants. They are also grateful to CES (Centre for Energy Studies), IAT (Institute of Appropriate Technology) and CERM (Centre for Environment \& Resource Management) of BUET (Bangladesh University of Engineering \& Technology) for their support.

\section{References}

[1] A. Srivasata and R. Prasad, "Triglyceride Based Diesel Fuels," Renewable and sustainable Energy Reviews, Vol. 4, No. 2, pp. 111-133, 2000.

[2] C. C. Akoh and B.G. Swanson, "Base Catalyzed Transesterification of Vegetable Oils," Journal of Food Processing \& Preservation, Vol. 12, pp. 139-149, 1988.

[3] M. Mirhosseini, "Assessing the Wind Energy Potential Locations in Province of Semnan in Iran," Renewable and Sustainable Energy Reviews, Vol. 15, No. 1, pp. 449-459, 2011.

[4] A.K Hossain and O. Badr, "Prospects of Renewable Energy Utilization for Electricity Generation in Bangladesh," Renewable and Sustainable Energy Reviews, Vol. 11, Issue 8, pp. 1617-1649, 2007.

[5] A.K.M.S Islam, M. Islam, and T. Rahman, "Effective Renewable Energy Activities in Bangladesh," Renewable Energy, Vol. 31, Issue 5, pp. 677-688, 2006.

[6] M.R. Islam and M. R. A. Beg, "Renewable Energy Sources and Technology Practice in Bangladesh" Renewable and Sustainable Energy Reviews, Vol. 12, Issue 2, pp 299-343, 2008.

[7] S. I. Khan and A. Islam, "Performance Analysis of Solar Water Heater," Smart Grid and Renewable Energy, Vol. 2,
No.4, pp. 396-398, 2011.

[8] T. R Oke, "Initial Guidance to Obtain Representative Meteorological Observations at Urban Sites: Instruments and Observing Methods," World Meteorological Organization, Report No. 81, WMO/TD-No. 1250, 2006.

[9] BPDB, "Annual Report 2006-07," Bangladesh Power Development Board, Dhaka, 2007.

[10] M. Asaduzzaman, A.H.M.M. Billah, "Energy for the Future, in Centre for Policy Dialogue, Emerging Issuesin Bangladesh Economy: A Review of Bangladesh's Development 2005-2006," University Press Limited, Dhaka, 2008.

[11] S. C. Bhattacharyya, G. R. Timilsina, "Energy Demand Models for Policy Formulation: A Comparative Study of Energy Demand Models," The World Bank, Policy Research Working Paper - 4866, 2009.

[12] S. I. Khan, A. Islam, A. H. Khan, "Energy forecasting of Bangladesh in gas sector using LEAP software," Global Journal of Researches in Engineering, Vol. 11, No. 1, pp. 15-20, 2011.

[13] Z. M. Hasib, J. Hossain, S. Biswas, A. Islam, "Bio-Diesel from Mustard Oil: A Renewable Alternative Fuel for Small Diesel Engines," Modern Mechanical Engineering, Vol. 1, No. 2, pp. 77-83, 2011.

[14] “Annual Report 2008", Bangladesh Oil, Gas and Mineral Corporation (Petrobangla), Dhaka, 2009.

[15] A. Roy, "Reliable Estimation of Density Distribution in Potential Wind Power Sites of Bangladesh," International Journal of Renewable Energy Research, Vol.2, No.2, pp. 219-226, 2012.

[16] Z. Wadud, D. J. Graham, R. B. Noland, "Gasoline Demand with Heterogeneity in Household Responses," The Energy Journal, Vol. 31, No.1, pp 47-73, 2010.

[17] M. Mansha, S. Javed, M. Kazmi and N. Feroze, "Study of Rice Husk Ash as Potential Source of Acid Resistance Calcium Silicate," Advances in Chemical Engineering and Science (ACES), Vol. 1 No. 3, pp. 147-153, 2011. 